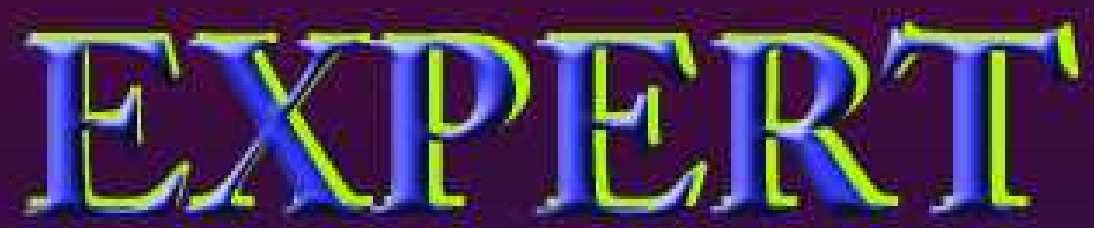

Jurnal Sistem Informasi

PERANCANGAN PROTOTYPE TEKNOLOGI SMART BUILDING MENGGUNAKAN ARDUINO BERBASIS WEB SERVER UNTUK MENDUKUNG PEMBANGUNAN PROPINSI LAMPUNG MENUJU PROGRAM LAMPUNG "SMART CITY"

Budi Usmanto, Tri Susilowati

SISTEM PENDUKUNG KEPUTUSAN PERANGKINGAN SEKOLAH MENENGAH KEJURUAN (SMK) DI KABUPATEN PRINGSEWU MENGGUNAKAN METODE WEIGHTED PRODUCT (WP)

Oktafianto, Elisabet Yunacti Anggracni, Suyono

OTORISASI PENGGUNA LABORATORIUM IBI DARMAJAYA BERBASIS CLIENT SERVER

Hendra Kurniawan, Hermanto

SISTEM PENDUKUNG KEPUTUSAN BERBASIS ANALYTICAL HIERARKHI PROCESS UNTUK PENENTUAN PENGISIAN JABATAN

Fenty Ariani

SEBARAN MENARA TELEKOMUNIKASI SELULER BERSAMA BERBASIS GIS (GEOGRAPHIC INFORMATION SYSTEM)

DI WILAYAH KABUPATEN LAMPUNG TENGAH

Taqwan Thamrin, Wiwin Susanty

AUTHENTIFIKASI LOGIN USER PADA PERANGKAT LUNAK MENGGUNAKAN ARDUINO DAN ENKRIPSI AES 256

Apri Triansah

ISSN : 2088-5555

$$
\text { Write To Be Experte }
$$




\section{Expert}

Jurnal Manajemen Sistem Informasi dan Teknologi

Volume 07, Nomor 02, Desember 2017

\begin{tabular}{|c|c|}
\hline Judul & Hal \\
\hline $\begin{array}{lllr}\text { PERANCANGAN } & \text { PROTOTYPE } & \text { TEKNOLOGI } & \text { SMART } \\
\text { BUILDING } & \text { MENGGUNAKAN ARDUINO BERBASIS WEB } \\
\text { SERVER } & \text { UNTUK } & \text { MENDUKUNG PEMBANGUNAN } \\
\text { PROPINSI LAMPUNG MENUJU PROGRAM LAMPUNG } \\
\text { "SMART CITY" }\end{array}$ & $57-65$ \\
\hline $\begin{array}{l}\text { SISTEM PENDUKUNG KEPUTUSAN PERANGKINGAN } \\
\text { SEKOLAH MENENGAH KEJURUAN (SMK) DI KABUPATEN } \\
\text { PRINGSEWU MENGGUNAKAN METODE WEIGHTED } \\
\text { PRODUCT (WP) }\end{array}$ & $66-71$ \\
\hline $\begin{array}{l}\text { OTORISASI } \quad \text { PENGGUNA } \quad \text { LABORATORIUM } \\
\text { DARMAJAYA BERBASIS CLIENT SERVER }\end{array}$ & $72-76$ \\
\hline $\begin{array}{l}\text { SISTEM PENDUKUNG KEPUTUSAN } \quad \text { BERBASIS } \\
\text { ANALYTICAL HIERARKHI PROCESS UNTUK PENENTUAN } \\
\text { PENGISIAN JABATAN }\end{array}$ & $77-82$ \\
\hline $\begin{array}{l}\text { SEBARAN MENARA TELEKOMUNIKASI SELULER } \\
\text { BERSAMA BERBASIS GIS (GEOGRAPHIC INFORMATION } \\
\text { SYSTEM) DI WILAYAH KABUPATEN LAMPUNG TENGAH }\end{array}$ & $83-89$ \\
\hline $\begin{array}{l}\text { AUTHENTIFIKASI LOGIN USER PADA PERANGKAT } \\
\text { LUNAK MENGGUNAKAN ARDUINO DAN ENKRIPSI AES } \\
256\end{array}$ & $90-95$ \\
\hline
\end{tabular}

Fakultas Ilmu Komputer

Universitas Bandar Lampung

\begin{tabular}{|c|c|c|c|c|}
\hline \multirow{2}{*}{ JMSIT } & Volume 07 & Nomor 02 & Lampung, Desember & ISSN \\
& & 2017 & $2088-5555$ \\
\hline
\end{tabular}




\section{TIM PENYUNTING}

\section{Penanggung Jawab}

Ahmad Cucus, S.Kom., M.Kom.

Ketua Tim Redaksi:

Taqwan Thamrin, ST, M.Sc.

Penyunting Ahli (Mitra Bestari):

Mustofa Usman, Ph.D (Universitas Lampung)

Dra. Wamiliana, MA., Ph.D (Universitas Lampung)

Iing Lukman, M.Sc., Ph. D (Universitas Malahayati)

\section{Penyunting:}

Fenty Ariani, S.Kom, M.Kom

Robby Yuli Endra, S.Kom.,M.Kom

Ayu Kartika Puspa, S.Kom, M.TI

Erlangga, S.Kom, M.Kom

\section{Pelaksana Teknis:}

Dian Resha Agustina, S.Kom

\section{Alamat Penerbit/Redaksi:}

Pusat Studi Teknologi Informasi

Fakultas Ilmu Komputer

Universitas Bandar Lampung

Gedung Business Center Lt.2

Jl. Zainal Abidin Pagar Alam No. 26

Bandar Lampung

Email: Journal.expert@ubl.ac.id 


\title{
AUTHENTIFIKASI LOGIN USER PADA PERANGKAT LUNAK MENGGUNAKAN ARDUINO DAN ENKRIPSI AES 256
}

\author{
APRI TRIANSAH \\ Program Studi Teknik Informatika \\ Fakultas Ilmu Komputer \\ Insitute Informatics And Business Darmajaya \\ Jalan Zainal Abidin Pagar Alam Bandar Lampung - Lampung - Indonesia 35142 \\ Telp. 0721 - 787214 Fax. 0721 - 700261 \\ website : http://darmajaya.ac.id \\ apri.triansahedarmajaya.ac.id
}

\begin{abstract}
ABSTRAK
Proses authentifkasi ketika ingin menggunakan suatu software biasanya menggunakan form login yang terdiri dari inputan username dan password. Cara ini dinilai rentan, karena bisa saja user melupakan username dan password. Kemungkinan lainnya, username dan password digunakan oleh orang lain yang tidak dinginkan atau username dan password tercuri. Arduino dapat digunakan untuk melakukan proses komputasi dan menyimpan data di dalamnya. Sehingga arduino dapat untuk melakukan proses enkripsi. Arduino dan software berkomunisasi lewat serial. Pemanfaatkan arduino untuk melakukan proses authentifikasi dinilai dapat memudahkan user sehingga tidak perlu mengingat username dan password. Kunci private tersimpan di dalam arduino. Komunikasi antara arduino dan software di enkripsi dengan metode AES sehingga mencegah kebocoran data. Cara ini dapat diimplementasikan pada software yang membutuhkan pengamanan tingkat tinggi dimana level pengamanan dilakukan secara hardware. Jika arduino tidak terhubung maka software tidak dapat digunakan. Bebrapa pengujian menunjukan dari tingkat kecepatan proses authentifikai didapatkan hasil tercepat 1 detik dan terlama 3 detik dalam kondisi ideal.
\end{abstract}

\section{Kata Kunci : arduino, AES, serial komunikasi}

\section{PENDAHULUAN}

Suatu perangkat lunak menggunakan username dan password untuk dapat login kedalam sistemnya. Namun kadang user melupakan username dan passwordnya karena terlalu banyak memiliki username dan password. Menulis username dan password sangat tidak direkomendasikan.

Penggunaan kunci berupa perangkat keras memudahkan user untuk dapat login kedalam sistem, karena user tidak harus mengingat username dan password. Perangkat keras ini di ibaratkan seperti kunci rumah.

Perangkat keras yang digunakan terdiri dari microcontroller arduino. Microcontroller ini dapat digunakan sebagai penyimpan password dan alat untuk melakukan verifikasi user.

Penggunaan dari penelitian ini dapat diimplementasikan untuk pengamanan tingkat tinggi, misalnya untuk membuka sebuah dokumen rahasia, akses level pada penggunaan software atau bahkan mengunci sebuah PC.

\subsection{Rumusan Masalah}

Bagaimana membangun sebuah perangkat keras berbasis arduino sebagai alat untuk melakukan verifikasi sebuah software dengan menggunakan enkripsi AES-256

\subsection{Batasan Masalah}

Penelitian ini dibatasi pada metode enkripsi AES yang digunakan hanya memiliki kunci sepanjang 256 bit. Arduino yang digunakan berkomunikasi dengan PC menggunakan serial. Software yang dibangun hanya melakukan verifikasi terhadap arduino dan menampilkan hasil jika verifikasi sukses/gagal

\subsection{Tujuan dan Manfaat Penelitian 1.4.1 Tujuan Penelitian}

Penelitian ini memiliki tujuan untuk Membuat sebuah perangkat keras untuk digunakan sebagai kunci untuk membuka software

\subsubsection{Manfaat Penelitian}

Manfaat dari penelitian ini adalah :

1. Meningkatkan level pengamanan suatu software

2. Memudahkan user karena tanpa harus mengingat user name dan password

2 Tinjauan Pustaka dan Landasan Teori

\subsection{Tinjauan Pustaka}

Beberapa penelitian yang memiliki keterkaitan dengan penelitian ini adalah antara lain:

1. Enkripsi dan Dekripsi dengan Algoritma AES 256 Untuk Semua Jenis File yang dilakukan oleh Voni Yuniati, Gani Indriyanta dan Antonius Rachmat C

2. Implementasi Advanced Encryption standard (AES) Pada Sistem Kunci Elektronik Kendaraan 
Berbasis Sistem Operasi Android Dan Mikrokontroler Arduino

\subsection{Landasan Teori}

\subsubsection{AES}

AES adalah metode kriptografi yang memiliki kunci simetrik. Metode ini terdiri dari 3 block chipper, AES-128, AES-192 dan AES-256. Masing-masing chipher melakukan enkripsi dan dekripsi data dalam blok 128 bit, 192 bit dan 256 bit. Kunci yang digunakan untuk melakukan enkripsi dan dekripsi harus diketahui oleh pengirim dan penerima [4].

\subsubsection{Kunci Simetrik}

Kunci simetrik dalam sistem kriptografi menggunakan kunci yang sama untuk enkripsi plain text dan dekripsi chipper text. Kunci simetrik memiliki keuntngan antara lain sederhana dan cepat. Namun, hal yang paling penting adalah bagaimana setiap bagian yang terlibat dapat bertukar kunci dengan cara yang aman [4].

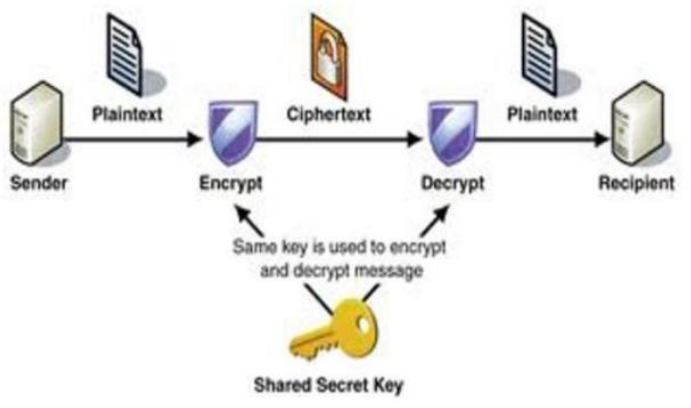

Gambar 1 Skema Kunci Simetrik

(sumber: S. Rawal, 2016)

\subsubsection{Kunci Public}

Dalam perbandingan kritografi, kunci public menggunakan metode yang berbeda dengan kunci simetrik dalam hal melakukan enkripsi plaintext dan dekripsi chipertext [4].

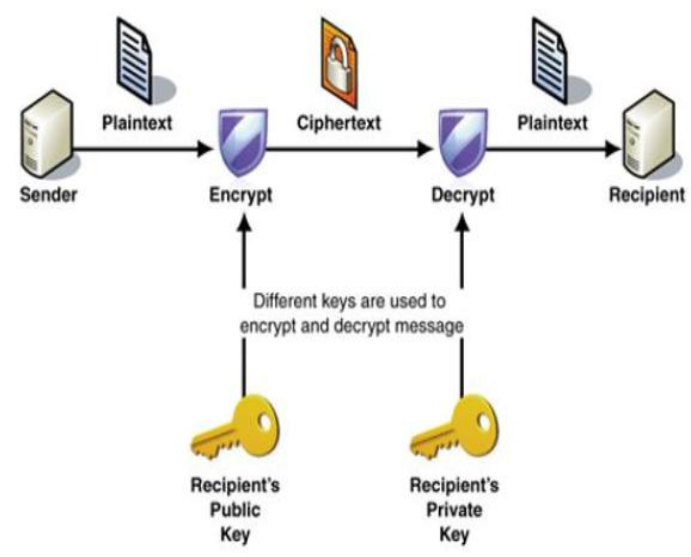

Kunci public menggunakan 2 kunci yang berbeda, yaitu kunci public untuk enkripsi dan kunci private untuk dekripsi. Dengan menggunakan sistem enkripsi seperti ini maka kunci public dapat di sebarkan dengan cara yang tidak aman. Kunci private tidak pernah di kirimkan dan hanya tersedia pada sisi penerima. Karena kuncinya berbeda, proses dekripsi dari chipper text tidak dapat dilakukan tanpa kunci private.

AES berdasarkan desain yang dikenal sebagai jaringan substitusi-permutasi, kombinasi dari keduanya, substitusi dan permutasi, cepat secara software dan hardware. Tidak seperti metode kriptograsi pendahulunya, DES. AES tidak menggunakan jaringan Feistel. AES adalah variasi dari Rijndel yang memiliki ukuran blok size tetap sepanjang 128 bit dan ukuran kunci sepanjang 128 , 192 atau 256 bit.

AES beroperasi pada matrik ukuran 4 x 4 kolom byte yang berurut disebut dengan state, walaupun beberapa versi dari Rijndael memiliki ukuran block yang lebih besar dan tambahan kolom dalam state. Kebanyakan perhitungan AES dikerjakan dalam bidang terbatas[5].

Sebagai contoh, jika terdapat 16 byte b0, b1,...b15 yang digambarkan dalam matrik sebagai berikut:

\begin{tabular}{|l|l|l|l|}
\hline b0 & b4 & b8 & b12 \\
\hline b1 & b5 & b9 & b13 \\
\hline b2 & b6 & b10 & b14 \\
\hline b3 & b7 & b11 & b15 \\
\hline
\end{tabular}

Ukuran kunci yang digunakan untuk menentukan jumlah putaran perulangan tranformasi yang mengubah inputan, disebut plaintext, kedalam output terakhir yang disebut chipper text. Jumlah siklus dalam perulangan adalah sebagai berikut:

a. 10 siklus perulangan untuk kunci 128 bit

b. 12 siklus perulangan untuk kunci 192 bit

c. 14 siklus perulangan untuk kunci 256 bit

Tiap putaran terdiri dari bebrapa langkah proses, masing-masing memiliki stage yang mirip tapi berbeda. Termasuk yang bergantung dengan kunci enkripsi itu sendiri. Satu putaran terbalik diterapkan untuk merubah chipper text kedalam plaintext menggunakan kunci enkripsi yang sama[6]

Gambar 2 Skema Kunci Publik 


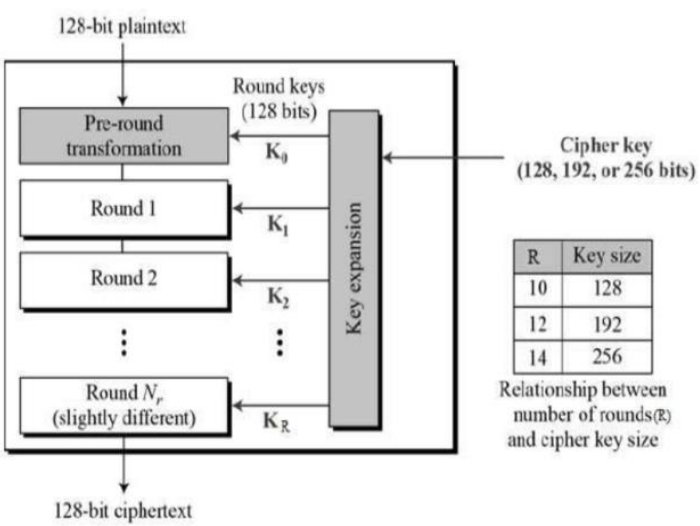

Gambar 3 Struktur AES

\subsubsection{Komunikasi Serial}

Komunikasi serial adalah komunikasi yang pengiriman datanya per-bit secara berurutan dan bergantian. Komunikasi ini mempunyai suatu kelebihan yaitu hanya membutuhkan satu jalur dan kabel yang sedikit dibandingkan dengan komunikasi paralel. Pada prinsipnya komunikasi serial merupakan komunikasi dimana pengiriman data dilakukan per bit sehingga lebih lambat dibandingkan komunikasi parallel, atau dengan kata lain komunikasi serial merupakan salah satu metode komunikasi data di mana hanya satu bit data yang dikirimkan melalui seuntai kabel pada suatu waktu tertentu. Pada dasarnya komunikasi serial adalah kasus khusus komunikasi paralel dengan nilai $\mathrm{n}=1$, atau dengan kata lain adalah suatu bentuk komunikasi paralel dengan jumlah kabel hanya satu dan hanya mengirimkan satu bit data secara simultan.Hal ini dapat disandingkan dengan komunikasi paralel yang sesungguhnya di mana n-bit data dikirimkan bersamaan, dengan nilai umumnya $8 \leq \mathrm{n} \leq 128[5]$.

Komunikasi serial ada dua macam, asynchronous serial dan synchronous serial. Synchronous serial adalah komunikasi dimana hanya ada satu pihak (pengirim atau penerima) yang menghasilkan clock dan mengirimkan clock tersebut bersama-sama dengan data. Contoh pengunaan synchronous serial terdapat pada transmisi data keyboard. Asynchronous serial adalah komunikasi dimana kedua pihak (pengirim dan penerima) masingmasing menghasilkan clock namun hanya data yang ditransmisikan, tanpa clock. Agar data yang dikirim sama dengan data yang diterima, maka kedua frekuensi clock harus sama dan harus terdapat sinkronisasi. Setelah adanya sinkronisasi, pengirim akan mengirimkan datanya sesuai dengan frekuensi clock pengirim dan penerima akan membaca data sesuai dengan frekuensi clock penerima. Contoh penggunaan asynchronous serial adalah pada Universal Asynchronous Receiver Transmitter (UART) yang digunakan pada serial port (COM) komputer.
Antarmuka Kanal serial lebih kompleks/sulit dibandingkan dengan antarmuka melalui kanal paralel, hal ini disebabkan karena:

1. Dari Segi perangkat keras: adanya proses konversi data pararel menjadi serial atau sebaliknya menggunakan piranti tambahan yang disebut UART (Universal Asynchronous Receiver/Transmitte) dan

2. Dari Segi perangkat lunak: lebih banyak register yang digunakan atau terlibat

Namun di sisi lain antarmuka kanal serial menawarkan berapa kelebihan dibandingkan secara paralel, antara lain:

1. Kabel untuk komunikasi serial bisa lebih panjang dibandingkan dengan paralel; data-data dalam komunikasi serial dikirim-kan untuk logika ' 1 ' sebagai tegangan $-3 \mathrm{~s} / \mathrm{d}-25$ volt dan untuk logika ' 0 ' sebagai tegangan $+3 \mathrm{~s} / \mathrm{d}+25$ volt, dengan demikian tegangan dalam komunikasi serial memiliki ayunan tegangan maksimum 50 volt, sedangkan pada komunikasi paralel hanya 5 volt. Hal ini menyebabkan gangguan pada kabel-kabel panjang lebih mudah diatasi dibandingkan pada parallel.

2. Jumlah kabel serial lebih sedikit; Anda bisa menghubungkan dua perangkat komputer yang berjauhan dengan hanya 3 kabel untuk konfigurasi null modem, yaitu TXD (saluran kirim), RXD(saluran terima) dan Ground, bayangkan jika digunakan teknik paralel akan terdapat $20-25$ kabel. Namun pada masing-masing komputer dengan komunikasi serial harus dibayar "biaya" antarmuka serial yang agak lebih mahal.

3. Banyaknya piranti saat ini (palmtop, organizer, hand-phone dan lainlain) menggunakan teknologi infra merah untuk komunikasi data, dalam hal ini pengiriman datanya dilakukan secara serial. IrDA-1 (spesifikasi infra merah pertama) mampu mengirimkan data dengan laju 115,2 kbps dan Konsep Komunikasi Serial 2 dibantu dengan piranti UART, hanya panjang pulsa berkurang menjadi 3/16 dari standar RS-232 untuk menghemat daya.

4. Untuk teknologi embedded system, banyak mikrokontroler yang dilengkapi dengan komunikasi serial (baik seri RISC maupun CISC) atau Serial Communication Interface (SCI); dengan adanya SCI yang terpadu pada $1 \mathrm{C}$ mikrokontroler akan mengurangi jumlah pin keluaran, sehingga hanya dibutuhkan 2 pin utama TxD dan RxD (di luar acuan ground). 


\section{METODE PENELITIAN}

\subsection{Perancangan Sistem}

Berikut ini gambaran block sistem secara umum.

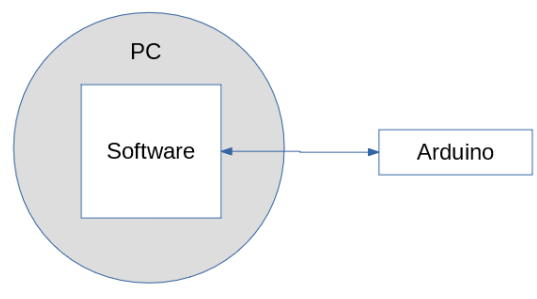

Gambar 4 Diagram Block Sistem

Arduino terhubung ke PC melalui komunikasi serial. Software yang ada melakukan verifikasi terhadap arduino. Apabila arduino mengirim data valid maka software dapat dijalankan.

\subsection{Alur Sistem}

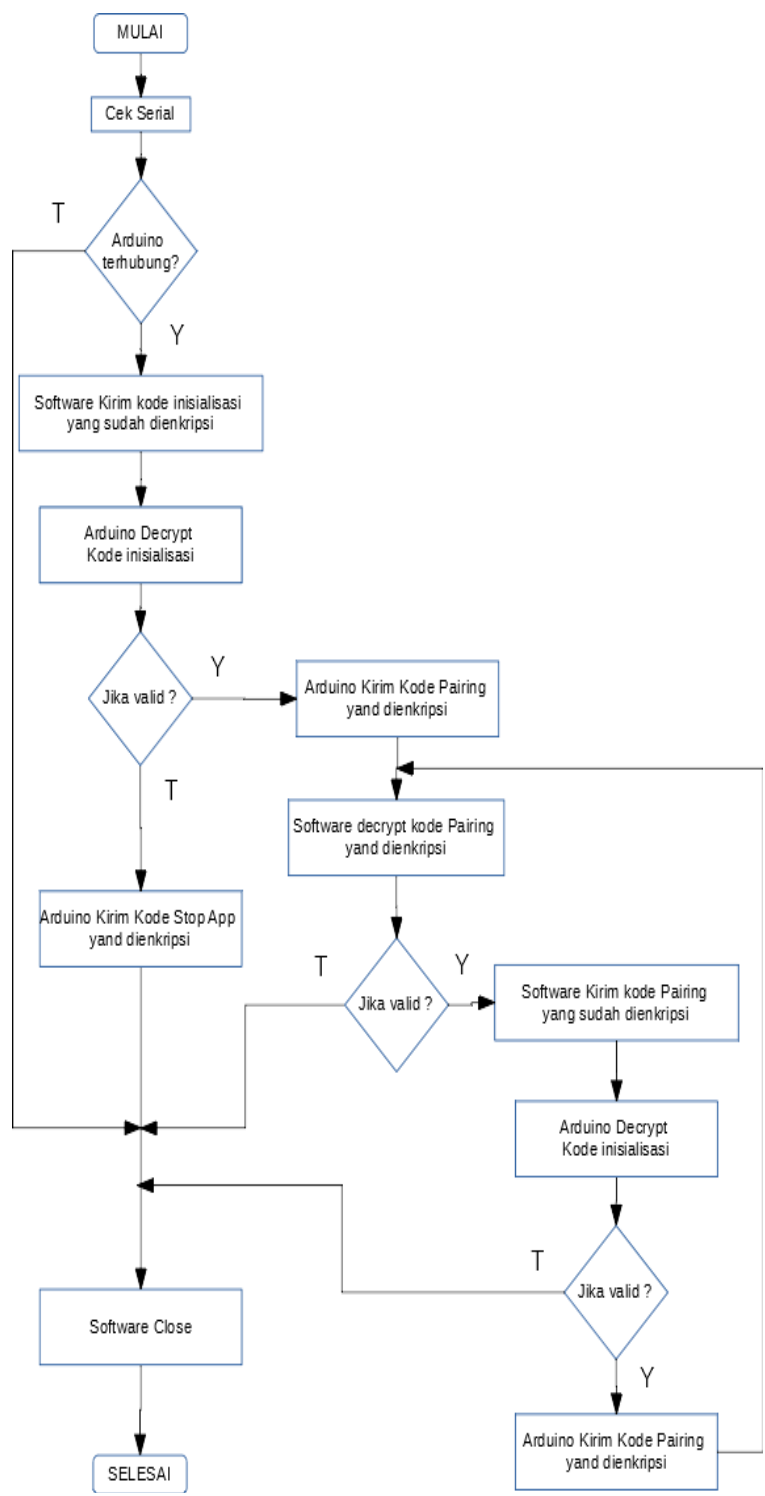

Gambar 5 Alur Sistem

\section{PEMBAHASAN}

4.1 Hardware

Hardware yang digunakan adalah arduino nano.

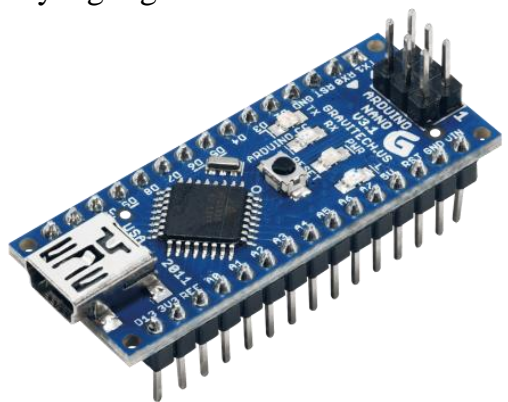

Gambar 6 Arduno Nano V3

Pada penelitian ini ditambahkan case agar terhidar dari debu dan air. Kunci private di simpan di dalam EPROM arduino.

\subsection{Software}

Berikut ini adalah tampilan dari software yang menggunakan authentifikasi melalui hardware.

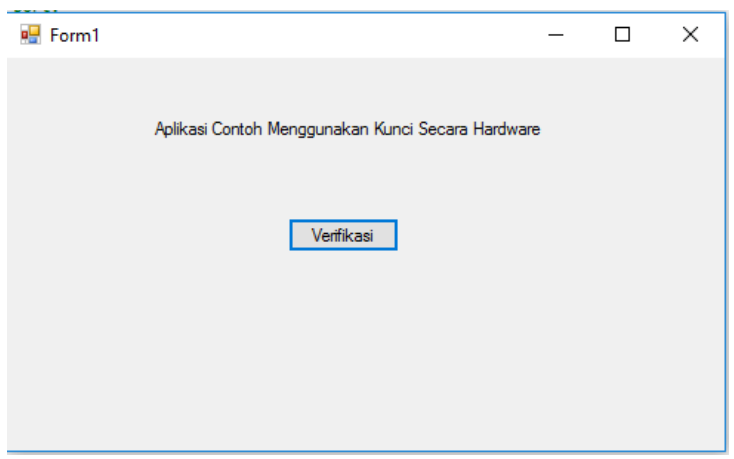

Gambar 7 Software untuk menguji verifikasi

Jika arduino terkoneksi maka software akan otomatis terverifikasi. Jika tidak terhubung dan arduino memiliki key yang salah maka software tidak terverifikasi.

\subsection{Pengujian}

Proses pengujian dilakukan dengan menggunakan scenario berikut ini:

1. PC dihidupkan lalu software dijalankan lalu hardware di hubungkan

2. Arduino dihubungkan ke pc dalam kondisi mati, lalu PC dinyalakan. Kemudian software dijalankan.

3. PC dihidupkan lalu arduino dihubungkan ke pc kemudian software dijalankan

4. Arduino dilepas dari PC yang sudah hidup dan software yang sedang jalan.

Pada pengujian nomor 1, ketika software dijalankan dan arduino belum dihubungkan. Software tidak mengenali userlogin. Ketika arduino dihubungkan, pc langsung mengenali perangkat. Software mendeteksi adanya arduino dan mengirim beberapa pesan yang digunakan untuk saling berhubungan. 
Software kemudian mengisikan userlogin sesuai dengan data yang ada di arduino

Pada pengujian nomor 2, PC langsung mendeteksi arduino dan ketika software di jalankan maka software kemudian mengisikan userlogin sesuai denfan data yang ada di arduino.

Pada pengujian nomor 3, PC mendeteksi arduino ketika dihubungkan. Kemudian software dijalankan lalu software mendeteksi userlogin yang ada di arduino

Pada pengujian nomor 4. Ketika arduino dilepas ketika software sudah login maka, software akan keluar dari loginnya.

Untuk pengujian data yang terjadi antara software dan arduino akan di munculkan dalam monitoring serial.

\subsection{Monitoring Serial}

Dengan menggunakan software freeserialmonitor dilakukan proses untuk capture data yang mengalir antara software dan hardware. Data tersebut akan dilihat apakah dapat di dekrip atau tidak. Berikut ini data yang tertangkap

Tabel 1. Data yang dikirim ke arduino dari software

\begin{tabular}{|c|c|c|}
\hline WAKTU & $\begin{array}{l}\text { KIRIM KE } \\
\text { ARDUINO(D } \\
\text { ARI PC) }\end{array}$ & TEXT \\
\hline $\begin{array}{l}\text { 000184: } 2017- \\
12-25 \\
08: 05: 03.9203 \\
150 \\
+0.5438792\end{array}$ & $\begin{array}{l}50414952 \\
0 \mathrm{~A}\end{array}$ & PAIR. \\
\hline $\begin{array}{l}000212: 2017- \\
12-25 \\
08: 05: 04.8975 \\
069 \\
+0.9668960\end{array}$ & $\begin{array}{l}4745545553 \\
45524 \mathrm{E} 41 \\
\text { 4D } 450 \mathrm{~A}\end{array}$ & $\begin{array}{l}\text { GETUSERNA } \\
\text { ME. }\end{array}$ \\
\hline $\begin{array}{l}\text { 000254: } 2017- \\
12-25 \\
08: 05: 05.8975 \\
913 \\
+0.9915281\end{array}$ & $\begin{array}{l}4745545553 \\
4552545950 \\
450 A\end{array}$ & $\begin{array}{l}\text { GETUSERTYP } \\
\text { E. }\end{array}$ \\
\hline $\begin{array}{l}\text { 000296: } 2017- \\
\text { 12-25 } \\
08: 05: 07.8976 \\
518 \\
+1.9846331\end{array}$ & $\begin{array}{l}50494 \mathrm{E} 47 \\
0 A\end{array}$ & PING. \\
\hline $\begin{array}{l}\text { 000358: } 2017- \\
12-25 \\
08: 05: 08.8977 \\
745 \\
+0.9863425\end{array}$ & $\begin{array}{l}50494 \mathrm{E} 47 \\
0 \mathrm{~A}\end{array}$ & PING. \\
\hline $\begin{array}{l}000428: 2017- \\
12-25 \\
08: 05: 09.8978 \\
196 \\
+0.9693320\end{array}$ & $\begin{array}{l}50494 \mathrm{E} 47 \\
0 \mathrm{~A}\end{array}$ & PING. \\
\hline 000490: 2017- & 5049 4E 47 & PING. \\
\hline
\end{tabular}

\begin{tabular}{|l|l|l|}
\hline $12-25$ & $0 \mathrm{~A}$ & \\
$08: 05: 10.8978$ & & \\
919 & & \\
+0.9883394 & & \\
\hline
\end{tabular}

Tabel 2 . Data balasan dari arduino berupa kode yang sudah terenkripsi.

\begin{tabular}{|c|c|c|}
\hline WAKTU & $\begin{array}{l}\text { RESPON } \\
\text { DARI } \\
\text { ARDUINO }\end{array}$ & TEXT \\
\hline $\begin{array}{l}000195: 2017- \\
12-25 \\
08: 05: 03.9305 \\
065 \\
+0.0000024\end{array}$ & $\begin{array}{l}5355 \text { 4B } 53 \\
4553 \text { OD 0A }\end{array}$ & SUKSES.. \\
\hline $\begin{array}{l}000223: 2017- \\
12-25 \\
08: 05: 04.9059 \\
196 \\
+0.0000042\end{array}$ & $\begin{array}{l}41707269 \\
20547269 \\
61 \quad 6 E 7361 \\
68 \text { OD } 0 A\end{array}$ & Apri Triansah.. \\
\hline $\begin{array}{l}\text { 000265: 2017- } \\
\text { 12-25 } \\
08: 05: 05.9128 \\
635 \\
+0.0000023\end{array}$ & $\begin{array}{l}41646 \mathrm{D} 69 \\
6 \mathrm{E} 697374 \\
7261746 \mathrm{~F} \\
72 \text { 0D 0A }\end{array}$ & Administrator.. \\
\hline $\begin{array}{l}\text { 000307: 2017- } \\
\text { 12-25 } \\
08: 05: 07.9111 \\
476 \\
+0.0000018\end{array}$ & $\begin{array}{l}5875574 \mathrm{D} \\
57775744 \\
79377 \mathrm{~A} 73 \\
477674 \text { 4E } \\
43733478 \\
5677 \text { 3D 3D } \\
0 \mathrm{~A}\end{array}$ & $\begin{array}{l}\text { XuWMWwWD } \\
\text { y7zsGvtN } \\
\text { Cs4xVw==. }\end{array}$ \\
\hline $\begin{array}{l}\text { 000369: 2017- } \\
\text { 12-25 } \\
08: 05: 08.9021 \\
230 \\
+0.0000028\end{array}$ & $\begin{array}{l}6270 \text { 2B } 70 \\
654 C \quad 4873 \\
38383657 \\
77567962 \\
58394167 \\
53413 \mathrm{D} \text { 3D } \\
0 A\end{array}$ & $\begin{array}{l}\text { bp+peLHs886W } \\
\text { wVyb } \\
\text { X9AgSA==. }\end{array}$ \\
\hline $\begin{array}{l}\text { 000438: } 2017- \\
12-25 \\
08: 05: 09.9094 \\
257 \\
+0.0000028\end{array}$ & $\begin{array}{l}3135535 \mathrm{~A} \\
6 \mathrm{E} 585572 \\
7445754 \mathrm{E} \\
6 \mathrm{~A} 533273 \\
43543462 \\
\text { 4D } 673 \mathrm{D} 3 \mathrm{D} \\
0 \mathrm{~A}\end{array}$ & $\begin{array}{l}\text { 15SZnXUrtEuN } \\
\text { jS2s } \\
\text { CT4bMg==. }\end{array}$ \\
\hline $\begin{array}{l}000501: 2017- \\
12-25 \\
08: 05: 10.9002 \\
803 \\
+0.0000028\end{array}$ & $\begin{array}{l}\text { 6F 6F 77 4C } \\
30703430 \\
49306 \mathrm{~B} 54 \\
616 \mathrm{~F} 3055 \\
\text { 2B 51 61 6C } \\
\text { 6A 67 3D 3D } \\
\text { 0A }\end{array}$ & $\begin{array}{l}\text { oowL0p40I0kTa } \\
\text { o0U } \\
\text { +Qaljg==. }\end{array}$ \\
\hline
\end{tabular}




\section{KESIMPULAN DAN SARAN}

\subsection{KESIMPULAN}

Metode ini dapat digunakan untuk mengamankan sebuah software dari penggunaan yang tidak diijinkan.

dan harus didekrip dengan kunci private yang benar.

\subsection{SARAN}

Penelitian ini dapat di tingkatkan dengan menggunakan metode enkripsi yang lebih cepat seperti Twofish atau Serpent. Selain itu proses transfer data antara komunikasi serial software dan arduino dibuat lebih stabil. Dapat mengubah serta menyimpan private key kedalam hardware dan software

Dokumen tersebut dibuka dengan menggunakan software tertentu. Software ini melakukan proses pengecekan terhadap microcontroller secara berkala untuk memastikan bahwa yang membuka data adalah orang yang berhak. Aliran data antara software dan microcontroller di enkripsi dengan metode AES sehingga meningkatkan level pengamanan software.

Software tidak dapat dijalankan jika microcontroller tidak terhubung dengan pc.
Beberapa scenario menunjukan kestabilan proses antara pembacaan serial dan proses enkrip/dekrip pada software dan hardware.

Monitoring pada serial menunjukan data yang melewati serial tidak dapat di buka secara langsung

\section{DAFTAR PUSTAKA}

[1] AF Ramdhansya, E Ariyanto, HH Nuha. 2014, Implementasi Advanced Encryption Standard (AES) Pada Sistem Kunci Elektronik Kendaraan Berbasis Sistem Operasi Android Dan Mikrokontroler Arduino. Seminar Nasional Informatika (SEMNASIF)

[2] ST Johannesen. 2014. Cryptoprocessing on the Arduino. Master Tesis. Norwegian University of Science and Technology Faculty of Information Technology, Mathematics and Electrical Engineering Department of Computer and Information Science

[3] Yuniati, V dkk. 2009. Enkripsi Dan Dekripsi Dengan Algoritma Aes 256 Untuk Semua Jenis File. Jurnal Informatika 5(1), 22 - 31

[4] S. Rawal. 2016. Advanced Encryption Standard (AES) and It's Working. International Research Journal of Engineering and Technology 3(8), $1165-1169$

[5] Tjhin, Santo dkk . 2014. Sistem Keamanan Sepeda Motor Melalui Short Message Service Menggunakan AVR Mikrokontroler Atmega8. Seminar Nasional Teknologi Informasi dan Komunikasi. Yogyakarta

[6] obbertin , Hans.2004.The Cryptanalysis of the AES - $\quad$ A $\quad$ Brief Survey 


\title{
Template Penulisan Jurnal Expert
}

\author{
First Author ${ }^{\# 1}$, Second Author ${ }^{* 2}$, Third Author ${ }^{\# 3}$ \\ ${ }^{\#}$ First-Third Department, First-Third University \\ Address Including Country Name \\ ${ }^{1}$ first.authorefirst-third.edu \\ ${ }^{3}$ third.authorefirst-third.edu \\ *Second Company \\ Address Including Country Name \\ ${ }^{2}$ second. authoresecond. com
}

\section{Abstrak}

Abstrak dalam bahasa Indonesia ditulis dengan rata kiri-kanan, dengan satu spasi dan satu kolom. Kata "Abstrak" sebagai judul ditulis dalam huruf Times 11-point, tebal, rata tengah, dengan huruf pertama dikapitalkan. Teks abstrak ditulis dengan huruf Times 10-point, satu spasi, sampai lebih kurang 150 kata. Sesudah abstrak tuliskan kata kunci dari makalah tersebut dalam daftar kata kunci. Kemudian dilanjutkan dengan teks utama makalah.

Kata kunci : : kata kunci abstrak

\section{Pendahuluan}

Semua makalah ditulis dalam bahasa Indonesia. Panduan penlisian ini dilengkapi dengan deskripsi huruf, spasi, dan informasi lainnya yang berhubungan dengan penulisan makalah anda. Diharapkan semua penulis dapat mengikuti template yang disediakan dan jika terdapat pertanyaan, silahkan menghubungi editor jurnal EXPERT di journal.expert@ubl.ac.id atau telefon +62721774626 .

\section{Format penulisan}

Materi yang akan dicetak, meliputi teks, gambar ilustrasi, dan grafik harus berada dalam area pencetakan yaitu bidang kertas A4 dengan margin 2.5 $\mathrm{cm}$ di semua sisi kertas. Jangan menuliskan atau meletakkan sesuatu diluar bidang cetak tersebut Seluruh teks ditulis dalam format dua kolom dengan lebar kolom $7.5 \mathrm{~cm}$ dan jarak antar kolom $1 \mathrm{~cm}$, kecuali bagian abstrak yang dituliskan dalam format satu kolom. Seluruh teks harus rata kiri-kanan.

Template ini menggunakan format yang dianjurkan. Untuk mempermudah penulis dalam memformat makalah/jurnalnya, format ini dapat digunakan sebagai petunjuk atau format dasar penulisan.

\section{Judul utama}

Judul utama (pada halaman pertama) harus dituliskan dengan jarak margin $2 \mathrm{~cm}$ dari tepi kertas, rata tengah dan dalam huruf Times 14-point, tebal, dengan huruf kapital pada huruf pertama dari kata benda, kata ganti benda, kata kerja, kata sifat, dan kata keterangan; jangan menggunakan huruf kapital pada kata sandang, kata hubung, terkecuali jika judul dimulai dengan kata-kata tersebut. Sisakan satu 11point baris kosong sesudah judul.

\section{Nama penulis dan afiliasi}

Nama penulis dan afiliasi diletakkan ditengah dibawah judul dan dituliskan dengan huruf Times 11point, tidak tebal. Afiliasi dan email penulis dituliskan dibawahnya dengan huruf Times 10-point, miring. Penulis yang lebih dari satu orang dituliskan dalam dua atau tiga kolom, dengan afiliasi dan email masingmasing.

\section{Tipe huruf}

Huruf yang digunakan adalah turunan dari huruf Times, meliputi Times Roman atau Times New Roman. Jika tipe huruf tersebut didak tersedia pada aplikasi pengolah kata yang digunakan, usahakan untuk memilih huruf yang memiliki kemiripan sedekat mungkin dengan Times. Hindari penggunaan huruf bit-mapped. Diharapkan untuk menggunakan huruf-huruf True-type 1.

\section{Teks utama}

Ketik teks utama dengan menggunakan huruf Times 10-point, satu spasi. Jangan menggunakan dua spasi. Setiap paragraf sebaiknya memiliki panjang lebih kurang $0.5 \mathrm{~cm}$. Pastikan teks ditulis dengan rata kiri-kanan. Jangan menambahkan baris kosong di antara paragraf. Istilah dalam bahasa asing (foreign language) yang tidak dapat diterjemahkan dalam bahasa utama makalah harus dituliskan dalam huruf miring.

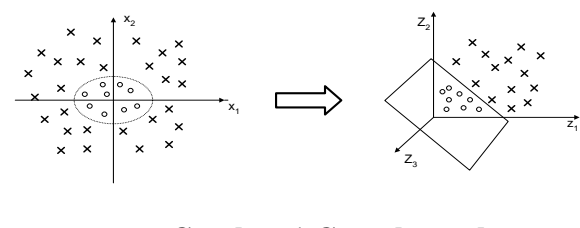

\section{Gambar 1 Contoh gambar}

Keterangan gambar dan tabel dituliskan dengan huruf Times 9-point. Sedangkan pengacuan gambar pada teks menggunakan huruf Times 10-pont. Keterangan gambar diletakkan di bawah, tengah gambar yang dijelaskan. Keterangan tabel diletakkan sebelum tabel dengan rata kiri.

Uraian yang dalam bentuk list (bulleted) dituliskan untuk:

- Uraian yang tidak memiliki aturan pengurutan tertentu

- Uraian yang tidak terikat antara uraian yang satu dan lainnya 


\begin{tabular}{|l|l|l|}
\hline No. & Jumlah & Kecepatan \\
\hline 1. & 25 & $10 \mathrm{~s}$ \\
\hline 2. & 50 & $15 \mathrm{~s}$ \\
\hline
\end{tabular}

Sedangkan untuk uraian yang berurutan dituliskan dengan penanda huruf, untuk:

a. Uraian yang memiliki aturan pengurutan

b. Uraian yang terkait dengan uraian lainnya

c. Uraian yang setiap itemnya akan diacu pada tulisan utama

\section{Judul pertama}

Sebagai contoh, "1. Pendahuluan", dituliskan dalam huruf Times 11-point, tebal, huruf pertama kata pertama ditulis dengan huruf kapital. Gunakan tanda titik (".") sesudah nomor judul.

\subsection{Judul kedua}

Sebagaimana judul pertama, judul kedua dituliskan dengan huruf Times 11-point, tebal. Nomor judul terdiri dari dua angka yang dibatasi dengan tanda titik. Tidak ada titik sesudah nomor judul dengan teks judul.

\subsubsection{Judul ketiga}

Untuk uraian yang lebih panjang dan tidak dapat dituliskan dalam bentuk uraian terurut, digunakan judul ketiga. Judul ketiga menggunakan ukuran huruf yang lebih kecil dari judul pertama dan judul kedua yaitu huruf Times 10-point, tebal. Nomor judul terdiri dari tiga angka yang dibatasi dengan tanda titik. Tidak ada titik sesudah nomor judul dengan teks judul.

\section{Catatan kaki}

Penggunaan catatan kaki dimaksudkan untuk membatu pembaca memperoleh penjelasan terhadap kalimat dalam teks tulisan utama. Catatan kaki dituliskan pada bagian bawah kolom yang memuat acuan ke catatan kaki tersebut. Catatan kaki ditulis dengan huruf Times 8-point, satu spasi. Hindari penggunaan banyak catatan kaki.

\section{Pemrograman}

Listing program dan disain algoritma dituliskan dengan menggunakan huruf dengan lebar yang tetap seperti Courier New 9-point.

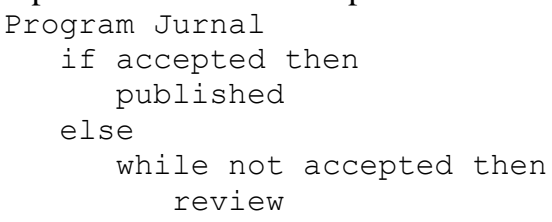

Sedangkan notasi matematika dituliskan dengan menggunakan simbol notasi yang sesuai.

\section{Daftar pustaka}

Daftar pustaka memuat daftar bacaan yang diacu dalam tulisan utama. Daftar pustaka ditulis dengan metode penulisan kepustakaan APA (American Psychological Association) Style, dengan huruf Times 10 -point. Kutipan dalam teks utama yang mengacu kepada daftar pustaka dituliskan dengan angka dalam kurung siku [nama penulis, tahun].

[1] A.B. Smith, C.D. Jones, and E.F. Roberts, Article Title, "Journal", Publisher, Location, Date, Years, pp. 1-10.

[2] Jones, C.D., A.B. Smith, and E.F. Roberts, Book Title, Publisher, Location, Date.

[3] S. Zhang, C. Zhu, J. K. O. Sin, and P. K. T. Mok, "A novel ultrathin elevated channel lowtemperature poly-Si TFT," IEEE Electron Device Lett., vol. 20, pp. 569-571, Nov. 2016. 
Redaksi :

Pusat Studi Teknologi Informasi (PSTI). Gedung Business Center Lt 2 J. Zainal Abidin No. 26 Bandar Lampung Telp. 0721 - 774626 9 772088 " 555000

SistemInformasi@ubl.ac.id 